\title{
Temporal bone hemangioendothelioma as a rare vascular tumor in childhood: case report and review of the literature
}

\author{
Begümhan Demir Gündoğan ${ }^{1 \oplus}$, Elvan Çağlar Çıtak ${ }^{1 \oplus}$, Fatih Sağcan ${ }^{1 \oplus}$, Kaan Esen $^{2 \odot}$, \\ Altan Yıldız ${ }^{2 \odot}$, Rabia Bozdoğan Arpaci ${ }^{3 \odot}$ \\ Departments of ${ }^{1}$ Pediatric Oncology, ${ }^{2}$ Radiology, and ${ }^{3}$ Pathology, Mersin University Faculty of Medicine, Mersin, Turkey.
}

\begin{abstract}
Background. Hemangiondothelioma is a rare vascular tumor that can occur in the bone. Temporal bone involvement has been reported extremely rare in the literature.

Case. Radiological examination of a one-year-old girl who was admitted due to facial paralysis revealed vascular tumor of the temporal bone and Galen vein aneurysm. Pathological examination showed retiform hemangioendothelioma. She was treated with propranolol, prednisolone, vincristine, and endovascular embolization followed by oral sirolimus. With sirolimus treatment, a partial response was obtained first, then the tumor remained stable and sirolimus treatment was discontinued. No progression was observed in the disease after discontinuation of treatment.
\end{abstract}

Conclusion. In this article, a case of hemangioendothelioma originating from the temporal bone is discussed in the light of other case reports in the literature.

Key words: hemangioendothelioma, temporal bone, galen vein aneurysm, sirolimus, childhood.

Primary vascular tumors of the bone are rare and consist of a wide range of different clinicopathological entities, from benign lesions to malignant tumors. Bone hemangioma is the most common benign vascular bone tumor. Vascular tumors vary from local aggressive tumors such as hemangioendothelioma to malignant tumors such as angiosarcoma. ${ }^{1}$

Hemangioendothelioma is the term used to name for vascular neoplasms that show a borderline biological behavior, intermediate between entirely benign hemangiomas and highly malignant angiosarcomas. ${ }^{2}$ Hemangioendothelioma can occur at any age, but is more frequently seen in adults. These lesions mainly affect the long bones; more than half of them are located in the tibia or femur. Temporal bone involvement of

$凶$ Elvan Çağlar Çıtak

caglarcitak@yahoo.com

Received 3rd December 2019, revised 19th March 2020, accepted 25th March 2020. hemagioendothelioma is extremely rare in the areas of the involved bone.

In this report, we present a child with hemangioendothelioma, a rare vascular tumor of the temporal bone, and a galen vein aneursym.

\section{Case Report}

An otherwise healthy one-year-old girl was admitted to our department with acute onset right peripheral facial nevre palsy for 10 days. According to the history obtained from her parents, 10 days prior her parents realized that she could not close her right eye while crying. She had no otalgia or otorrhea complaint at the time. On physical examination, the head was slightly asymmetric with a right temporal prominence, narrowing of the right external auditory canal, and right facial paresis. There was no pain in the lesion. There was no history of paresthesias and neurological deficit or similar lesions on other parts of the body. It was firm 
and non compressible. There was no regional lymphadenopathy, and the patient did not have any history of constitutional symptoms such as fever, weight loss or loss of appetite. Total blood count and biochemical analysis were within normal range. Cranial computed tomography (CT) scan showed expansile and lytic lesion on the right temporal bone (Fig. 1A). Cerebral magnetic resonance imaging (MRI), inner ear MRI and cerebral MRI angiography revealed fluid-fluid levels in the right mastoid cells and lytic lesion with pronounced hypervascular feature in an expanding character (Fig. 1 B). Anterior venous malformation between galen vein and posterior cerebral artery and also dilated feding and draining vessels suggesting galen vein aneursym was seen in cerebral MRI (Fig. 1C). Temporal bone biopsy was done. Histopathologic examination of the mass showed narrow arborizing vascular channels forming a retiform pattern and spindle cells which were focally obliterating the vessel wall. The vessels were lined by monomorphic hobnaillike endothelial cells, without significant pleomorphism. There were no mitoses and necrosis. Immunohistochemically, the tumor cells stained with CD31, CD34, and FLI-1 antibodies (Fig. 2. A,B,C,D,E). The diagnosis were compatible with retiform (intermediate grade) hemangioendothelioma.

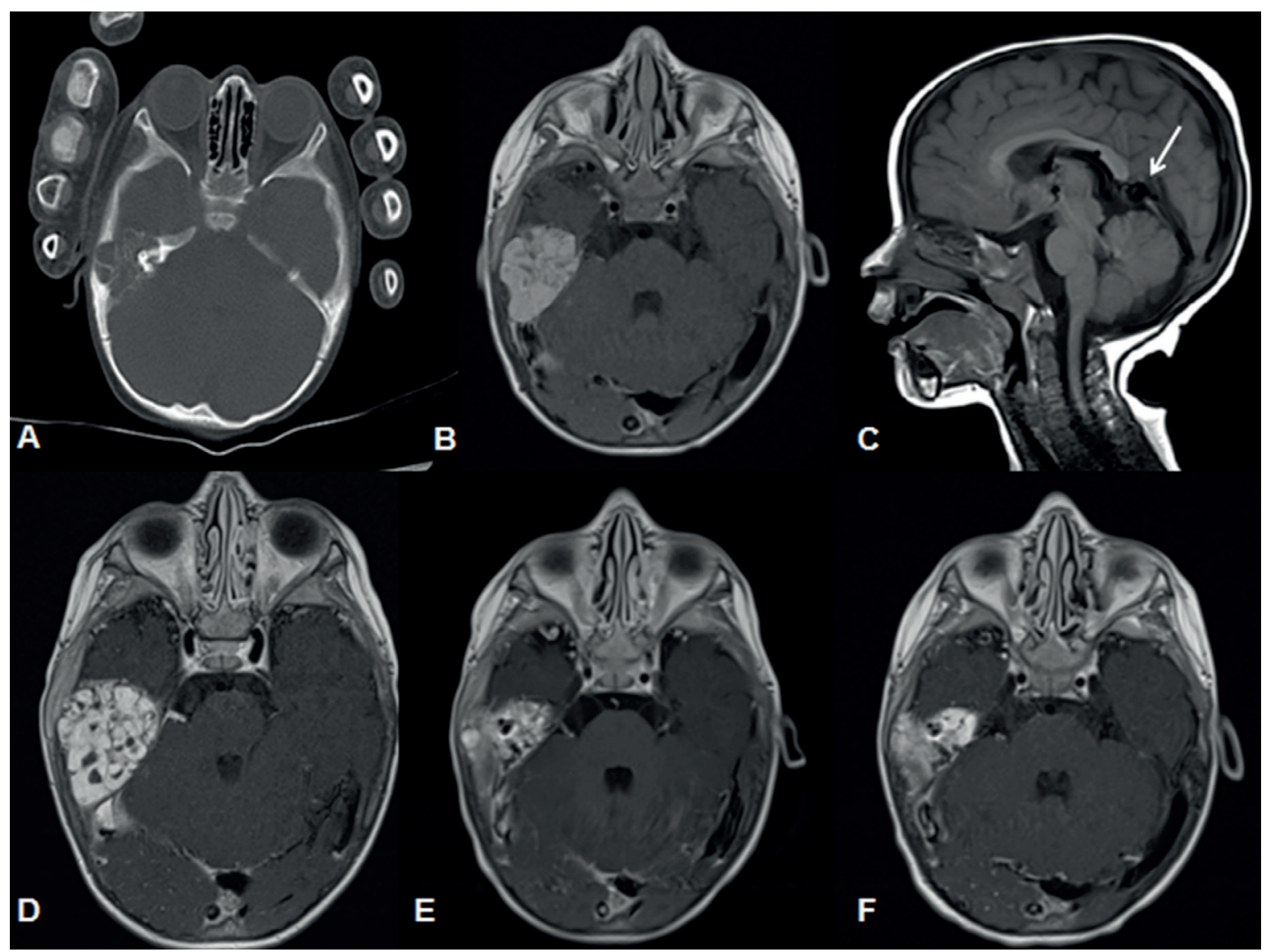

Fig. 1. (A): CT scan shows expansile and lytic lesion on the right temporal bone, (B): Contrast enhanced T1 weighted MR scan shows diffuse contrast enhancement of the lesion, (C): Sagittal view T1-weighted MR scan shows the enlarged median prosencephalic vein of Markowski, characteristic of vein of Galen aneurysmal malformation (arrow), (D): Contrast-enhanced T1-weighted MRI shows progression of the mass that completely fills mastoid air cells, (E): Contrast enhanced T1 weighted MR scan shows regression in mass size after embolization, (F): contrast enhanced T1-weighted MRI shows 9 months after sirolimus treatment minimal regression of mass size. 


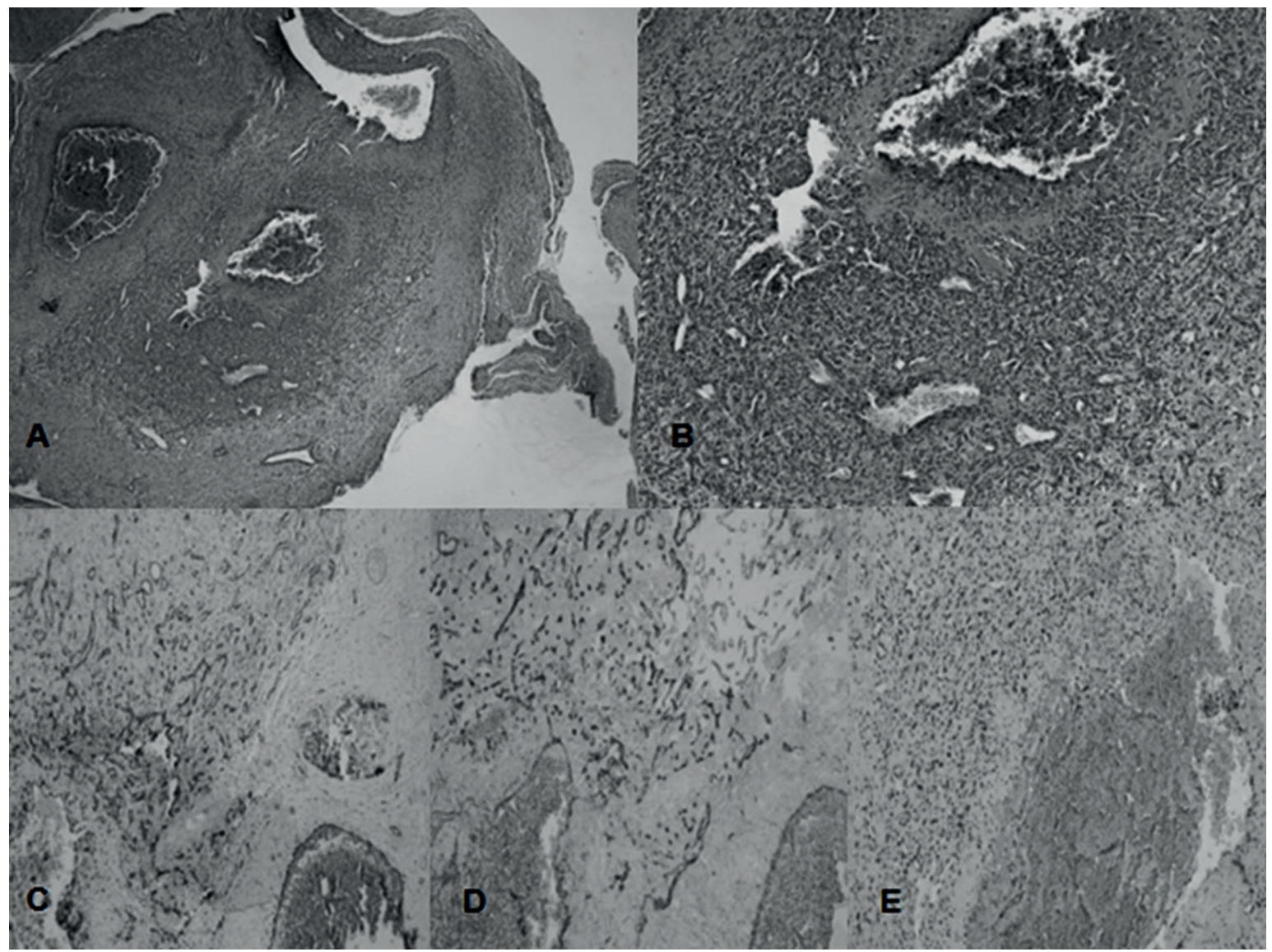

Fig. 2. (A): Tumor cells were obliterating the vessel wall (HE×100), (B): Tumor cells showed mild pleomorphism. Mitoses and necrosis were absent $(\mathrm{HE} \times 200),(\mathrm{C})$ : Tumor cells showed staining with CD31, $(\mathrm{CD} 31 \times 100)$, (D): Tumor cells showed staining with CD34, (CD34x100), (E): Tumor cells showed diffusely staining with FLI-1 (FLI-1x200).

Oral propranolol was started at a dose of 2 $\mathrm{mg} / \mathrm{kg} /$ day in two doses. One month after propranolol treatment, prednisolone was added to the treatment because of no significant change in the size of the mass on physical examination and minimal radiological progression. But her facial paralysis improved slightly. After one month follow-up period, cranial and inner ear MRI showed progression of the lesion, weekly vincristine $\left(1.5 \mathrm{mg} / \mathrm{m}^{2}\right)$ treatment was added and embolization treatment was planned for the hemangioendothelioma (Fig. 1D). After $5 \mathrm{~F}$ intraducer placement in the right femoral artery, the right anterior carotid artery and the outer carotid artery were reached, and the vascularity of the hypervascular lesion in the temporal bone and feeding vessels were detected, and embolization was performed from the two feeders (Fig. 3. A,B). After embolization, there was a slight decrease in the size of the lesion, there was a poor response to medical treatment (Fig. 1E). The treatment was switched to oral sirolimus. Sirolimus was started at $0.8 \mathrm{mg} / \mathrm{m}^{2}$ per dose twice daily with plasma level monitoring target of $10-15 \mathrm{ng} / \mathrm{ml}$. After nine months of sirolimus treatment, the lesion regressed and treatment response was defined as partial remission (Fig. 1F).

Sirolimus treatment was continued for a further three months after partial remission was achieved. Sirolimus treatment was discontinued after determining a stable disease in the evaluation of the tumor with control MR. No 


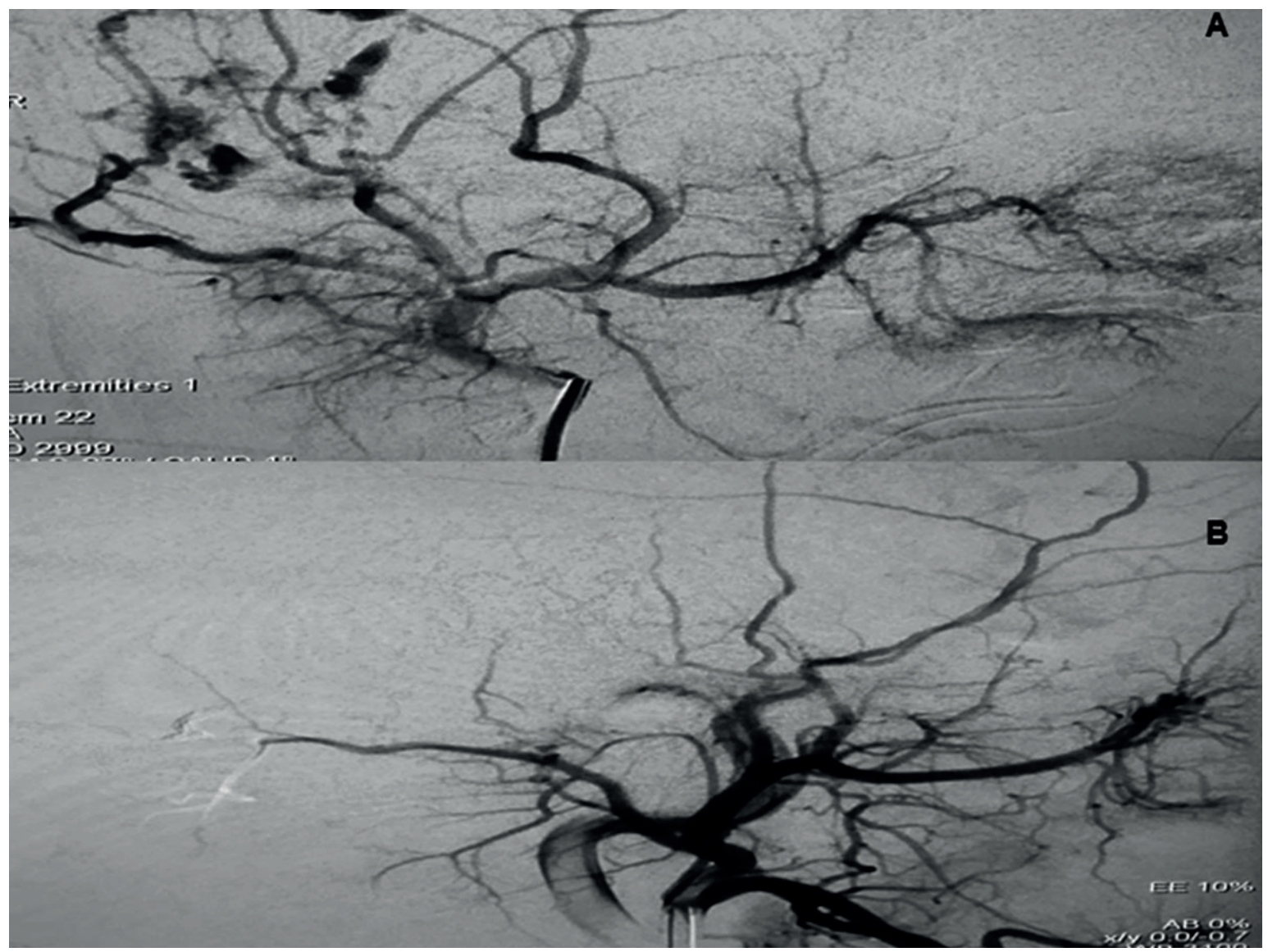

Fig. 3. (A): Lateral DSA image the external carotid artery shows vascular feeders of the lesion originated from frontal branch of the superfisial temporal artery and occipital artery, (B): Post-embolisation DSA images show nearly total oclussion of the feeder vessels and onyx cast.

progression was observed in the tumor three months after treatment was discontinued and the patient is still being followed up with stable disease Inform consent was received from the family

\section{Discussion}

Vascular tumors of the bone have a wide spectrum ranging from benign hemangiomas and epithelioid hemangiomas to intermediate grade hemangioendotheliomas to malignant angiosarcomas. For years, the classification of vascular tumors of the bone has been highly controversial, especially given the lack of consistent terminology, limited histological criteria, and limited correlations between clinical course and diagnosis.
Hemangioendotheliomas have a wide range of histological features and are classified as local aggressive or borderline tumors according to International Society for the Study of Vascular Anomalies (ISSVA). ${ }^{3}$ In this group, caposiform, retiform, composite, papillary intralymphatic (also known as Dabska tumor) and pseudomyogenic types are included, whereas epitheloid hemangioendothelioma belongs to malignant vascular tumor group in ISSVA classification.

Retiform hemangioendothelioma (RH) is a very rare intermediate or borderline vascular tumor with unknown etiology. Lymphedema, previous radiotherapy and non-epidermal malignant tumors have been proposed in the etiology of $\mathrm{RH}$, and in one case the relationship with human herpes virus $8(\mathrm{HHV}-8)$ has been 
Table I. Temporal bone hemangioendothelioma cases in English literature.

\begin{tabular}{|c|c|c|c|c|c|c|c|c|}
\hline Case & Author & $\begin{array}{c}\text { Age } \\
\text { (years) }\end{array}$ & Sex & Symptoms & Location & Angiography & Treatment & Follow-up \\
\hline 1 & $\begin{array}{l}\text { Jochaims } \\
\text { et al. }\end{array}$ & 19 & M & $\begin{array}{l}\text { Tinnitus } \\
\text { Earache } \\
\text { Discharge } \\
\text { Hearing loss }\end{array}$ & Mastoid & NA & $\begin{array}{l}\text { Surgery } \\
\text { radiotherapy }\end{array}$ & 3 year \\
\hline 2 & $\begin{array}{l}\text { Goldestien } \\
\text { et al. }\end{array}$ & 62 & M & $\begin{array}{l}\text { Tinnitus } \\
\text { Hearing loss } \\
\text { Vertigo } \\
\text { Mass }\end{array}$ & Middle ear & $\begin{array}{l}\text { Normal } \\
\text { angiogram }\end{array}$ & $\begin{array}{l}\text { Surgery } \\
\text { radiotherapy }\end{array}$ & 1 year \\
\hline 3 & $\begin{array}{l}\text { Eliashar } \\
\text { et al. }\end{array}$ & 3 & M & $\begin{array}{l}\text { Retroauricular } \\
\text { swelling } \\
\text { Tendeness } \\
\text { Fever } \\
\text { Lymphadenophathy }\end{array}$ & Mastoid & NA & A interferon & NA \\
\hline 4 & Lalaji et al. & 1 & F & Mass & Mastoid & NA & $\begin{array}{l}\text { Surgery } \\
\text { predisolon }\end{array}$ & 2 year \\
\hline 5 & Ibarra et al. & 5 & F & $\begin{array}{l}\text { Mass } \\
\text { Facial plasy }\end{array}$ & EAM & $\begin{array}{l}\text { Middle } \\
\text { meningeal } \\
\text { artery }\end{array}$ & Surgery & NA \\
\hline 6 & Kim et al. & 7 & M & Mass & Mastoid & $\begin{array}{l}\text { Branches of } \\
\text { the middle } \\
\text { meningeal } \\
\text { artery }\end{array}$ & $\begin{array}{l}\text { Partial } \\
\text { Surgery } \\
\text { Radiotherapy }\end{array}$ & $\begin{array}{l}\text { Recurrent } \\
2 \text { year } \\
\text { Radiotherapy } \\
\text { Chemotherapy }\end{array}$ \\
\hline 7 & $\begin{array}{l}\text { Chang et } \\
\text { al. }\end{array}$ & 1 & M & Facial palsy & $\begin{array}{l}\text { Internal } \\
\text { auditory } \\
\text { canal }\end{array}$ & $\begin{array}{l}\text { External } \\
\text { carotid } \\
\text { artery }\end{array}$ & $\begin{array}{l}\text { Surgery } \\
\text { Cortison } \\
\text { Interferon }\end{array}$ & 1 year \\
\hline 8 & $\begin{array}{l}\text { Panda et } \\
\text { al. }\end{array}$ & 38 & M & $\begin{array}{l}\text { Tinnitus } \\
\text { Hearing loss } \\
\text { Fullness of the ear } \\
\text { Dizziness }\end{array}$ & Middle ear & NA & Surgery & 6 months \\
\hline 9 & $\begin{array}{l}\text { Moskowitz } \\
\text { et al. }\end{array}$ & 6 & $\mathrm{~F}$ & $\begin{array}{l}\text { Facial palsy } \\
\text { Hearing loss } \\
\text { Dizziness } \\
\text { Tinnitus }\end{array}$ & Middle ear & NA & Surgery & NA \\
\hline 10 & $\begin{array}{l}\text { Tian WZ } \\
\text { et al. }\end{array}$ & 57 & $\mathrm{~F}$ & Mass & NA & NA & NA & Surgery \\
\hline 11 & This case & 1.5 & $\mathrm{~F}$ & $\begin{array}{l}\text { Facial palsy } \\
\text { Mass }\end{array}$ & Mastoid & $\begin{array}{l}\text { External } \\
\text { carotid } \\
\text { artery }\end{array}$ & $\begin{array}{l}\text { Propranolol } \\
\text { Prednisolone } \\
\text { Vincristine } \\
\text { Embolization } \\
\text { Sirolimus }\end{array}$ & 3 years \\
\hline
\end{tabular}


reported. ${ }^{4}$ It is characterized by a high rate of local recurrence and a low frequency of metastasis, and its biologic potential is between that of hemangiomas and angiosarcomas. Histologically, the tumor exhibits arborizing elongated blood vessels, hobnail monomorphic endothelial cells with scant cytoplasm and no significant atypia, prominent endovascular papillae with collagenous cores, and prominent lymphocytic infiltrate. ${ }^{5,6}$ To our knowledge, no more than 50 cases have been described in the literature since the first description in all age groups according to diagnostic criteria. $\mathrm{RH}$ is usually seen in young and middle-aged people, but rarely in children. So far, the youngest patient described in the literature was 6 and the oldest was 78 years old. To our knowledge our patient is the youngest diagnosed case in the literature. $^{7}$

Although RT originating from various cranial bones and sphenoid wing has been reported, to our knowledge $\mathrm{RH}$ originating from temporal bone like our case has not been reported to date. Temporal bone tumors especially vascular tumors are rare. Ramadan O. ${ }^{8}$ analysed and reviewed 45 manuscripts of temporal bone origin malignant vascular tumors, which have been published so far and whose data are available, of 47 cases described in these manuscripts 9 (19\%) were diagnosed as hemangioendothelioma. To our knowledge, to date, 13 cases of hemangioendothelioma originating from temporal bone have been reported, none of them were $\mathrm{RH}$ histology. ${ }^{9-21}$ Eleven of 13 cases whose data can be accessed including our case are summarized in the table (Table I). Seven of these cases are under 18 years of age. The ratio of males to females is $6 / 5$ in the reported cases. Mastoid bone was reported to be the most common site as in our case. Surgical treatment was performed in eight patients.

The most frequent radiographic finding of hemangioendothelium is an osteolytic sharply demarcated lesion but calcification and periost reaction are not usually seen. ${ }^{16} \mathrm{MR}$ findings of hemangioendothelioma are nonspecific. The signal intensity of these vascular structures may display as either high flow (low signal intensity on images of all pulse sequences) or low flow (high signal intensity on the T2-weighted images). ${ }^{16}$ In the CT scan images of our case, the mastoid air cells were almost completely filled with contrast enhanced mass on the right side. Cranial contrast-enhanced MRI showed a lytic hypervascular mass that almost completely filled the right mastoid air cells but did not cause destruction. Hyperintense hemosiderin residues were found in the mass in T1-weighted images, and fluid-liquid levels were found in T2-weighted images and and the mass was markedly enhanced in contrastenhanced images of our case. According to these radiological findings, our patient was thought to have a tumor of vascular origin. Although it was thought to be a vascular tumor radiologically, a biopsy was performed to determine the definitive diagnosis and treatment option and pathological examination of the lesion revealed retiform hemangioendothelioma.

The vein of Galen aneurysmal malformation (VGAM) is a rare congenital vascular malformation characterized by the shunting of the arterial flow into an enlarged cerebral vein of Galen. Its incidence is $1 / 25000$ and constitutes $1 \%$ of all cerebral vascular malformations and $30 \%$ of vascular malformations in children. ${ }^{22}$ Clinical presentations vary with the age of onset and vascular architecture. The main manifestations include congestive heart failure, hydrocephalus, and neurological symptoms. ${ }^{22}$ Our patient was asymptomatic and galen vein aneursym was found incidentally on cranial MRI. According to our knowledge, galen vein aneursym and temporal bone hemagioendothelioma have not been reported in the same patient before. We think that this coexistence is a coincidental finding.

Treatment for hemangioendothelioma may depend on the histologic type and the risk of recurrence or metastases. In our patient, medical treatment was planned due to its unsuitable locationfor surgery. 
In recent years, propranolol has been widely used in the treatment of infantile hemangioma and vascular tumors. ${ }^{23,24}$ Although the exact mechanism of action of propranolol is not clear, it has been reported that it acts on infantile hemangiomas by increasing vasoconstruction and apoptosis, reducing angiogenic factors and modulating renin-angiotensin system. Moreover, propranolol induces apoptosis and disrupts the migration of malignant vascular tumor cells. Infantile hemangiomas express high levels of beta adrenergic receptors potentially explaining their sensitively to propranolol, and these receptors have been reported to be strongly expressed in hemagioendothelioma and vascular malformations. ${ }^{25}$ In our case, we preferred propranolol treatment as the firstline treatment. However, no response was obtained despite one month of treatment of propranolol. Firstly prednisolone then weekly vincristine was added to the treatment. Four months after the initial treatment, cranial MRI showed minimal progression in the lesion, so embolization was performed and sirolimus treatment was initiated.

The mammalian target of rapamycin (mTOR) is a serine threonine kinase regulated by phosphoinositide 3 kinase (PI3K) and protein kinase $\mathrm{B}(\mathrm{Akt})$ that activates protein synthesis. mTOR plays a key role in the pathogenesis of various vascular anomalies, leading to angiogenesis and lymphangiogenesis by increasing VEGF expression, except that it plays an important role in cell growth and proliferation. ${ }^{26} \mathrm{mTOR}$ inhibitors directly inhibit mTOR, blocking downstream protein synthesis and presenting antitumoral and antiangiogenic effect. Sirolimus, also known as rapamycin is a mTOR inhibitor. Clinical data on the use of sirolimus in patients with vascular anomalies are rare and most of them are case reports. ${ }^{27,28}$

Since our patient did not respond to propranolol, prednisolone and vincristine treatments and the lesion showed slight progression, it was decided to try sirolimus treatment after embolization. An MRI was performed one month after embolization and regression of tumor volume was detected. MRI performed six months after sirolimus treatment showed significant regression in tumor size which defined the response to treatment as partial remission. Sirolimus treatment was continued. There were no complications during the treatment. This suggests that sirolimus is an option in the treatment of hemangioendothelioma.

In conclusion, hemangioendothelioma of the temporal bone origin is an extremely rare vascular tumor in childhood and its association with Galen vein aneurysm has not been previously described. In addition, sirolimus seems to be a safe and efficient treatment option for the treatment of hemangioendothelioma, but its effect should be supported by studies conducted in large series.

\section{REFERENCES}

1. Verbeke SL, Bovée JV. Primary vascular tumors of bone: a spectrum of entities? Int J Clin Exp Pathol 2011; 4: 541-551.

2. Requena L, Kutzner H. Hemangioendothelioma. Semin Diagn Pathol 2013; 30: 29-44

3. Wassef M, Blei F, Adams D, et al. ISSVA Board and Scientific Committee. Vascular anomalies classification: Recommendations from the International Society for the study of vascular anomalies. Pediatrics 2015; 136: e203-e214.

4. Kuo CL, Chen PC, Li WY, et al. Retiform hemangioendothelioma of the neck. J Pathol Transl Med 2015; 49: 171-173.

5. Nobeyama Y, Ishiuji Y, Nakagawa H. Retiform hemangioendothelioma treated with conservative therapy: report of a case and review of the literature. Int J Dermatol 2016; 55: 238-243.

6. Albertini AF, Brousse N, Bodemer C, Calonje E, Fraitag S. Retiform hemangioendothelioma developed on the site of an earlier cystic lymphangioma in a six-year-old girl. Am J Dermatopathol 2011; 33: e84-e87.

7. Pan BC, Wang CH, Huang GF, Tian XY, Li Z. Unusual multiple cutaneous retiform hemangioendothelioma on forearm and neck misdiagnosed as angiosarcoma with metastasis. Clin Diagn Pathol 2017; 1: 1-5.

8. Ramadan O. Malignant vascular tumors of temporal bones: review article. Glob J Otolaryngol 2016; 2: 555589 . 
9. Correa A, Hirschamann J. Hemangioendothelioma of the middle ear. Rev Bras Otorrinolaringol 1951; 19: 4-12.

10. Joachims HZ, Cohen Y. Hemangioendothelioma of the mastoid bone. Laryngoscope 1974; 84: 454-458.

11. Ershova VA, Diagilev VV. Hemangioendothelioma of the middle ear. Vestn Otorinolaringol 1987; 1: 6869.

12. Goldstein WS, Bowen BC, Balkany T. Malignant hemangioendothelioma of the temporal bone masquerading as glomus tympanicum. Ann Otol Rhinol Laryngol 1994; 103: 156-159.

13. Eliashar R, Saah D, Osin P, Sichel JY. Hemangioendothelioma of the temporal bone in a child. Int J Pediatr Otorhinolaryngol 1997; 40: 67-71.

14. Lalaji TA, Haller JO, Burgess RJ. A case of head and neck kaposiform hemangioendothelioma simulating a malignancy on imaging. Pediatr Radiol 2001; 31: 876-878.

15. Ibarra RA, Kesava P, Hallet KK, Bogaev C. Hemangioendothelioma of the temporal bone with radiologic findings resembling hemangioma. AJNR Am J Neuroradiol 2001; 22: 755-758.

16. Kim HL, Im SA, Lim GY, et al. High grade hemangioendothelioma of the temporal bone in a child: a case report. Korean J Radiol 2004; 5: 214-217.

17. Chang JM, Kwon BJ, Han MH, Kang HS, Chang KH. Kaposiform hemangioendothelioma arising from the internal auditory canal. AJNR Am J Neuroradiol 2006; 27: 931-933.

18. Panda NK, Rao SS, Karuppiah S, Vaiphei K, Sing P. Epithelioid hemangioendothelioma of middle ear masquerading as glomus tumor. Am J Otolaryngol 2007; 28: 69-71.
19. Moskowitz HS, Jaffe R, Hirsch BE. Epithelioid hemangioendothelioma of the middle ear in a child Am J Otolaryngol 2011; 32: 259-262.

20. Drazin D, Gandhi R, Slodkowska E, et al. Epithelioid hemangioendothelioma of the mastoid: resection for recurrence and adjuvant radiation with 8-year followup. Case Rep Surg 2013; 2013: 469201.

21. Tian WZ, Yu XR, Wang WW, Zhang B, Xia JG, Liu HQ. Computed tomography and magnetic resonance features of intracranial hemangioendothelioma: a study of 7 cases. Oncol Lett 2016; 11: 3105-3110.

22. Cao LR, Cai CQ. Vein of galen aneurysmal malformation: an updated review. J Pediatr Neurol 2019; 17: 45-56.

23. Erbay A, Sarialioglu F, Malbora B, et al. Propranolol for infantile hemangiomas: a preliminary report on efficacy and safety in very low birth weight infants. Turk J Pediatr 2010; 52: 450-456.

24. Corapcioğlu F, Büyükkapu-Bay S, Binnetoğlu K, Babaoğlu A, Anik Y, Tugay M. Preliminary results of propranolol treatment for patients with infantile hemangioma. Turk J Pediatr 2011; 53: 137-141.

25. Chisholm KM, Chang KW, Truong MT, Kwok S, West RB, Heerema-McKenney AE. $\beta$-Adrenergic receptor expression in vascular tumors. Mod Pathol 2012; 25: 1446-1451.

26. Lackner H, Karastaneva A, Schwinger W, et al. Sirolimus for the treatment of children with various complicated vascular anomalies. Eur J Pediatr 2015; 174: 1579-1584.

27. Akyuz C, Susam-Sen H, Aydin B. Blue rubber bleb Nevus syndrome: promising response to sirolimus. Indian Pediatr 2017; 54: 53-54.

28. Yesil S, Tanyildiz HG, Bozkurt C, Cakmakci E, Sahin G. Single-center experience with sirolimus therapy for vascular malformations. Pediatr Hematol Oncol 2016; 33: 219-225. 